\title{
Variation in $\beta$-amylase activity and thermostability in Tibetan annual wild and cultivated barley genotypes*
}

\author{
Hai-tao ZHANG, Tian-long CHEN, Bing-lin ZHANG, De-zhi WU, \\ Ye-chang HUANG, Fei-bo WU, Guo-ping ZHANG ${ }^{\dagger *}$ \\ (Department of Agronomy, College of Agriculture and Biotechnology, Zhejiang University, Hangzhou 310058, China) \\ †E-mail: zhanggp@zju.edu.cn \\ Received Jan. 28, 2014; Revision accepted May 8, 2014; Crosschecked Aug. 7, 2014
}

\begin{abstract}
Amylase activity (BAA) and thermostability (BAT) are important traits for malt quality. In this study, 138 Tibetan annual wild barley accessions and 20 cultivated genotypes differing in BAA were planted and analyzed in 2009 and 2012. Significant differences were detected among genotypes in BAA and BAT. The cultivated genotypes had a mean BAA of $1137.6 \mathrm{U} / \mathrm{g}$ and a range of from 602.1 to $1407.5 \mathrm{U} / \mathrm{g}$, while the wild accessions had a mean of $1517.9 \mathrm{U} / \mathrm{g}$ and a range of from 829.7 to $2310.0 \mathrm{U} / \mathrm{g}$. The cultivated genotypes had a mean relative residual $\beta$-amylase activity (RRBAA) of $61.6 \%$ and a range of from $22.2 \%$ to $82.3 \%$, while the wild barleys had a mean of $57.8 \%$ and a range of from $21.9 \%$ to $96.1 \%$. Moreover, there was a significant difference among genotypes in the response of RRBAA to the temperature and duration of heat treatment. The wild barleys had wider variation in BAA and BAT than cultivated genotypes.
\end{abstract}

Key words: Barley, $\beta$-Amylase activity, Thermostability, Tibet doi:10.1631/jzus.B1400026

Document code: A

CLC number: S335.3

\section{Introduction}

Barley (Hordeum vulgare L.) ranks fourth among the cereal crops in terms of planted area and production in the world (Zhou, 2010). It is characterized by multiple uses, but is used mainly for malting and animal feed. The rapid increase in beer and whisky consumption worldwide requires more malt barley grains with high quality. It has been well documented that diastatic power (DP), malt extract, and fermentability are major attributes determining malt quality (Ullrich et al., 1997; Agu et al., 2007).

\footnotetext{
\$Corresponding author

* Project supported by the National Natural Science Foundation of China (Nos. 31330055 and 31201205), the Zhejiang Provincial Natural Science Foundation of China (No. Z3110054), the 948 Project of Ministry of Agriculture of China (No. 2012-Z25), and the China Agriculture Research System (No. CARS-05)

(C) Zhejiang University and Springer-Verlag Berlin Heidelberg 2014
}

DP represents a hydrolytic ability of malt, degrading starch into fermentable oligosaccharides and maltose, and is significantly related to malt extract and fermentability, which in turn determine alcoholic output from barley grains or malt (Agu, 2003; Agu et al., 2007). The starch-degrading process involves the coordination of at least four enzymes, namely $\alpha$-amylase, $\beta$-amylase (EC 3.2.1.2; 1,4- $\alpha$-glucan maltohydrolase), limit dextrinase, and $\alpha$-glucosidase. Among them, $\beta$-amylase, which catalyzes the 1,4- $\alpha$ glycosidic linkages in the none-reducing end of the poly-glucan chain to release $\beta$-maltose, plays a key role during degradation of starch, and its activity is significantly correlated with DP (Delcour and Verschaeve, 1987; Gibson et al., 1995). Unlike the other three enzymes, which are synthesized during germination, $\beta$-amylase accumulates during seed development, and exists in seeds in free and bound forms (Hara-Nishimura et al., 1986; Hardie, 1975; Vinje et al., 
2011). Therefore, the content or activity of $\beta$-amylase in barley grains will be greatly affected by environmental factors. In addition, $\beta$-amylase thermostability (BAT) has a huge effect on wort fermentability (Evans et al., 2003). During brewing, starch saccharification or diastatic action is conducted at a constant temperature of $65^{\circ} \mathrm{C}$ or a variable temperature from 48 to $70{ }^{\circ} \mathrm{C}$, to enhance the degradation of starch rapidly and thoroughly (Eglinton et al., 1998). However, $\beta$-amylase shows lower thermostability than $\alpha$-amylase and limit dextrinase, and its activity decreases rapidly if the incubation temperature is over $55{ }^{\circ} \mathrm{C}$ (Thacker et al., 1992; Sjöholm et al., 1995). Therefore, BAT is also an important trait associated with malt quality.

Eglinton et al. (1998) identified four kinds of $\beta$-amylases, after making an intensive survey of natural variation in the enzyme thermostability in barley. Three alleles controlling $\beta$-amylase, Bmy1-Sd1, $B m y 1-\mathrm{Sd} 2 \mathrm{~L}$, and $B m y 1-\mathrm{Sd} 2 \mathrm{H}$, were detected in cultivated barley, while Bmy1-Sd3, controlling the $\beta$-amylase with high BAT, was found in wild barley (Hordeum vulgare L. ssp. spontaneum). These four $\beta$-amylases differ in irreversible heat inactivation, which is in turn related to original activation. The barley cultivars with the Bmyl-Sd1 allele showed moderate BAT, while the cultivars with Bmyl-Sd2 could be divided into two groups: high $(\mathrm{Sd} 2 \mathrm{H})$ and low (Sd2L) BAT. The wild barley with Bmyl-Sd3 had the highest BAT.

Accordingly, it has been an important objective in malt barley breeding to develop cultivars with high $\beta$-amylase activity (BAA) and BAT. The success of such a breeding program is greatly dependent on the availability of genetic diversity. Ahokas and Manninen (2000) reported that Finnish landrace barleys had a higher thermostability than cultivated barleys. Kaneko et al. (2001a) examined 6752 barley accessions from different areas of the world, and found that barley germplasm from China had a large variation in BAT. Recently, Gong et al. (2013) also reported that Chinese landrace and Tibetan wild barleys showed high BAA and were rich in $\beta$-amylase alleles. Tibetan annual wild barley is well-known for its wide genetic diversity (Dai et al., 2012). Thus, it may be possible for us to identify accessions with high BAA and BAT from Tibetan wild barley.
In the present study, we determined the BAA and BAT of 138 wild barley accessions collected from the Tibetan Plateau and 20 cultivated barley cultivars planted in 2009 and 2012. The objectives of this study were (1) to identify wild barley accessions with high BAA and BAT and (2) to compare the enzyme properties of Tibetan wild barley and cultivated barley.

\section{Materials and methods}

\subsection{Plant materials}

Tibetan wild barley accessions were kindly donated by Prof. Dong-fa SUN of Huazhong Agricultural University (China). In this study, 138 accessions of Tibetan wild barley $(H$. vulgare L. ssp. spontaneum, coded XZ) and 20 cultivars (H. vulgare L., including Danerdamai, Yanyin 1, Pudamai 4, 35-1, Fuxuan 48, Shang 1154, Clippey, Feiqi 5, Sabaylis, Chunfengpidamai, Haha, Bizhe, Layiba, Allaweinuw, Ticn, Qingyin 2916, Qingyin 3506, Mianyang 81-18, Fengaierleng, and Ai 49) were planted in Zijingang Farm, Zhejiang University, Hangzhou $\left(120.2^{\circ} \mathrm{E}\right.$, $30.5^{\circ} \mathrm{N}$ ), China, early in November 2008 and 2011, respectively. Each accession or cultivar was planted into a plot consisting of 5 rows, each $2 \mathrm{~m}$ long with $0.25 \mathrm{~m}$ between rows. All agronomic management practices were the same as those used locally in barley production. At maturity (late in May), grains from the three middle rows were harvested and dried naturally, then stored at $4{ }^{\circ} \mathrm{C}$ for further analysis.

\subsection{Measurement of BAA}

Barley grains were milled with a Cyclotec 1093 sample mill (Tecator AB, Höganäs, Sweden) and passed through a $0.5-\mathrm{mm}$ screen. Then, $0.5 \mathrm{~g}$ powder of each sample was used for BAA assay. BAA was determined with the BETAMYL- $3^{\circledR}$ kit (Megazyme International Ireland Ltd.) according to McCleary and Codd (1989) with slight modification. Three replicates were used for each measurement. For easy comparison, the unit of BAA was converted from BETAMYL- $3^{\circledR}$ to BETAMYL ${ }^{\circledR}$. One BETAMYL ${ }^{\circledR}$ unit is the amount of enzyme required to release $1 \mu \mathrm{mol}$ of $p$-nitrophenol from $p$-nitrophenyl- $\alpha$-Dmaltopentaose per minute. 


\subsection{Determination of BAT}

BAT was determined by a two-point assay method according to Eglinton et al. (1998). The BAT is expressed as the relative residual BAA (RRBAA), i.e., the amount of residual BAA after incubating the $\beta$-amylase extract in a $60{ }^{\circ} \mathrm{C}$ water bath for $10 \mathrm{~min}$, expressed as a percentage of the initial BAA in the grains.

\subsection{Change in RRBAA with temperature}

According to the results of above-mentioned two-point assay, Tibetan wild barley accessions, XZ174 and XZ7, and the cultivar Allaweinuw showed high, low, and moderate BATs, respectively. Hence, these three genotypes were used to study the change in BAT under a temperature change from 40 to $70{ }^{\circ} \mathrm{C}$.

\subsection{Change in RRBAA over time}

Eight representative genotypes according to the results from 2009 were selected, i.e., XZ25, Fuxuan 48, XZ174, and XZ31 with high BAT, XZ11 and cultivar Allaweinuw with moderate BAT, and XZ7 and cultivar Qingyin 3506 with low BAT. The examined genotypes were subjected to $60{ }^{\circ} \mathrm{C}$ incubation for a duration of $10,20,30,40,50$, or $60 \mathrm{~min}$.

\subsection{Data analysis}

Data were analyzed using SAS V8.0 (SAS Institute, Cary, NC, USA) and SigmaPlot 11.0 programs. Duncan's multiple range test was used to compare the significance of difference between treatments.

\section{Results}

\subsection{BAA}

In 2009, the BAAs of 20 barley cultivars ranged from 602.1 to $1407.5 \mathrm{U} / \mathrm{g}$, with a mean of $1137.6 \mathrm{U} / \mathrm{g}$ and a coefficient of variation $(\mathrm{CV})$ of $18.5 \%$. Compared with the cultivated barleys, Tibetan wild barleys had higher BAAs, ranging from 829.7 to $2310.0 \mathrm{U} / \mathrm{g}$, with a mean of $1517.9 \mathrm{U} / \mathrm{g}$ and a $\mathrm{CV}$ of $22.8 \%$ (Table 1). Among the Tibetan wild barleys, 71 accessions $(51.1 \%)$ exhibited higher BAA than the cultivars with the highest BAA.
Table 1 BAA and BAT in Tibetan wild and cultivated barleys

\begin{tabular}{ccccccc}
\hline \multirow{2}{*}{ Year } & \multirow{2}{*}{ Parameter } & \multicolumn{2}{c}{ BAA (U/g) } & & \multicolumn{2}{c}{ BAT (\%) } \\
\cline { 6 - 7 } \cline { 6 - 6 } & & Wild $^{\mathrm{a}}$ & Cultivated $^{\mathrm{b}}$ & & Wild & Cultivated \\
\hline \multirow{6}{*}{2009} & Min & 829.7 & 602.1 & & 21.9 & 22.2 \\
& Max & 2310.0 & 1407.5 & & 96.1 & 82.3 \\
& Mean & 1517.9 & 1137.6 & 57.8 & 61.6 \\
& CV $^{\mathrm{c}}$ & $22.8 \%$ & $18.5 \%$ & & $24.6 \%$ & $31.6 \%$ \\
& Min & 624.0 & 780.0 & 3.4 & 12.3 \\
& Max & 1913.1 & 1323.2 & & 87.4 & 80.7 \\
& Mean & 1315.4 & 1030.8 & & 38.4 & 38.4 \\
& CV & $23.5 \%$ & $16.4 \%$ & $50.7 \%$ & $60.1 \%$ \\
\hline
\end{tabular}

${ }^{\mathrm{a}}$ Wild, Tibetan wild barley, $n=138 .{ }^{\mathrm{b}}$ Cultivated, cultivated barley, $n=20 .{ }^{\circ} \mathrm{CV}$, coefficient of variation. Each value is the mean of three replicates for each genotype

In 2012, the BAA of 20 cultivars ranged from 780.0 to $1323.2 \mathrm{U} / \mathrm{g}$, with a mean of $1030.8 \mathrm{U} / \mathrm{g}$ and a CV of $16.4 \%$. Tibetan wild barleys showed wider variation in BAA, ranging from 624.0 to $1913.1 \mathrm{U} / \mathrm{g}$, with a mean of $1315.4 \mathrm{U} / \mathrm{g}$ and a $\mathrm{CV}$ of $23.5 \%$ (Table 1). There were 75 (54.0\%) Tibetan wild barley accessions with BAA higher than that of the cultivar with the highest BAA.

The mean and range of BAA in Tibetan wild barley were higher and wider, respectively, than those of the cultivars in 2009 and 2012 (Table 1). In addition, there was an obvious difference in BAA between the two years, with 2009 being higher than 2012 (Fig. 1). However, a significant correlation $\left(R^{2}=0.4670, P<\right.$ 0.0001 ) was found between the two years (Fig. 2).

\subsection{BAT}

In 2009, there was a large difference in BAT between the Tibetan wild and cultivated barleys (Table 1). The BAT of the 20 cultivars ranged from $22.2 \%$ to $82.3 \%$, with a mean of $61.6 \%$ and a CV of $31.6 \%$. The range in BAT among Tibetan wild barley accessions was from $21.9 \%$ to $96.1 \%$, with a mean of $57.8 \%$ and a CV of $24.6 \%$. Six wild accessions had a higher BAT than the cultivar with the highest BAT.

In 2012, the BAT of the 20 cultivars ranged from $12.3 \%$ to $80.7 \%$, with a mean of $38.4 \%$ and a CV of $60.1 \%$. The wild barley accessions had a wider range of BAT, from $3.4 \%$ to $87.4 \%$, with a mean of $38.4 \%$ and a CV of $50.7 \%$ (Table 1). Two wild barley accessions had higher BAT than the cultivar with the highest BAT. 

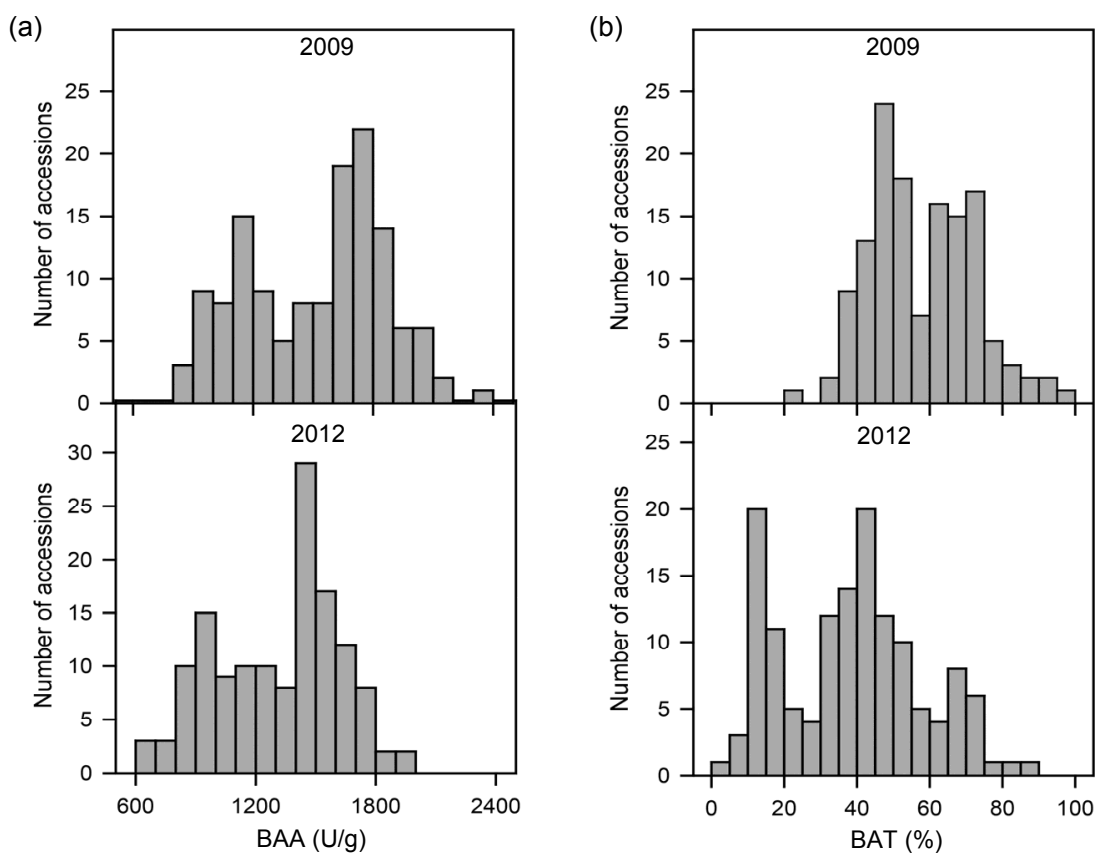

Fig. 1 Frequencies of BAA (a) and BAT (b) in 138 Tibetan wild barley accessions in 2009 and 2012

Top and bottom panels represent the results by using seeds harvested in 2009 and 2012, respectively. Each value is the mean of three replicates for each genotype
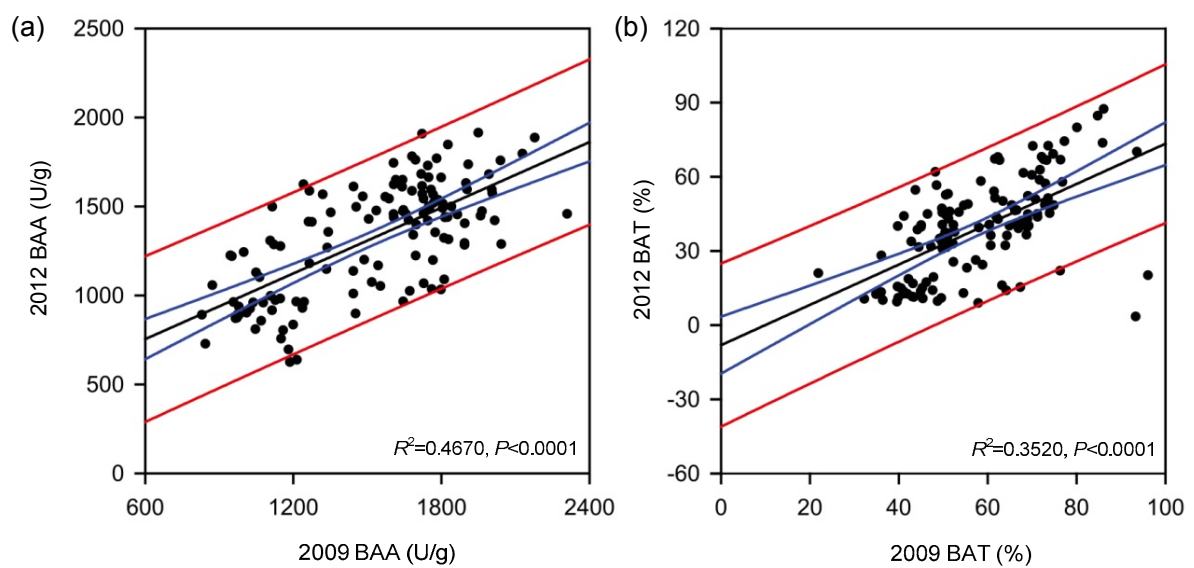

Fig. 2 Leverage plots of BAA (a) and BAT (b) in Tibetan wild barleys between 2009 and 2012

The black line presents the regression line between the two years; the space between the two blue lines present $95 \%$ confidence interval; the space between the two red lines present $95 \%$ prediction interval (Note: for interpretation of the references to color in this figure legend, the reader is referred to the web version of this article)

The range of BAT in Tibetan wild barley was wider than that in cultivated barleys in both 2009 and 2012 (Table 1). Across all wild genotypes examined, BAT was higher in 2009 than in 2012 (Fig. 1), and a significant correlation was found between the two years $\left(R^{2}=0.3520, P<0.0001\right)$ (Fig. 2$)$.

\subsection{Change in RRBAA with temperature}

The three barley genotypes examined differed dramatically in the response of BAA to changing temperature (Fig. 3). From 40 to $55{ }^{\circ} \mathrm{C}$, all three genotypes exhibited relatively high BAA, and from 65 to $70{ }^{\circ} \mathrm{C}$, their BAA declined to almost zero. XZ174 showed higher stability in BAA than the other two genotypes at increased temperatures, and its RRBAA remained as high as $85.9 \%$ in 2009 and $73.8 \%$ in 2012 , even when exposed to $60^{\circ} \mathrm{C}$. However, a rapid decline in enzyme activity was observed when the temperature rose to $65^{\circ} \mathrm{C}$. XZ7 showed the lowest stability of BAA among the three barley genotypes in 
terms of response to increased temperature. Its RRBAA was higher than that of the other two genotypes when the temperature was below $45^{\circ} \mathrm{C}$ in 2009 , but declined rapidly with increasing temperature in both 2009 and 2012. Between 55 and $65^{\circ} \mathrm{C}, \mathrm{XZ7}$ showed the lowest BAT. The cultivated barley Allaweinuw had a moderate BAT in response to temperature change in both 2009 and 2012.

We also evaluated the $T_{50}$, i.e., the temperature at which the RRBAA was reduced by $50 \%$. XZ174, Allaweinuw, and XZ7 had $T_{50}$ values of around 62.1, 60.8, and $58.6{ }^{\circ} \mathrm{C}$, respectively, in 2009 , and 61.6, 60.2 , and $57.5^{\circ} \mathrm{C}$, respectively, in 2012 (Fig. 3).

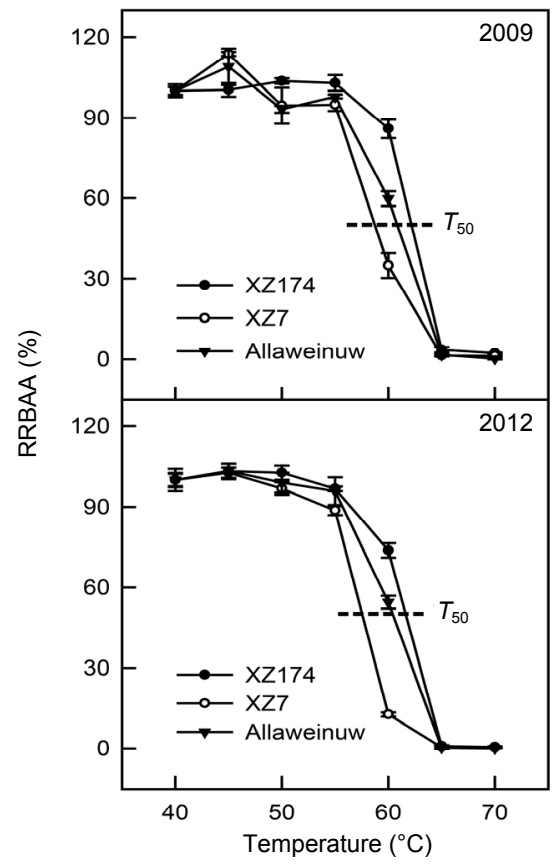

Fig. 3 Change in RRBAA with temperature Top and bottom panels represent the variation in RRBAA in seeds harvested in 2009 and 2012, respectively. $T_{50}$ refers to the temperature when RRBAA is $50 \%$. The germplasm coded XZ is Tibetan wild barley. Each value is the mean of three replicates for each genotype. Bars represent standard errors

\subsection{Change in RRBAA with duration of heat treatment}

Genotypic differences in BAT with the duration of heat treatment were determined (Fig. 4). XZ25 and Fuxuan 48 showed a high BAT according to the results of the previous two-point assay. The values of RRBAA in XZ25 remained higher than $80 \%$ during the first $10 \mathrm{~min}$ and were about $70 \%$ after $20 \mathrm{~min}$ and $50 \%$ after $30 \mathrm{~min}$ of heat treatment at $60^{\circ} \mathrm{C}$ in 2009 . In 2012 , the corresponding values were about $80 \%$ after $10 \mathrm{~min}$, below $60 \%$ after $20 \mathrm{~min}$ and $40 \%$ after $30 \mathrm{~min}$ of heat treatment. The Tibetan wild barley XZ7 and the cultivated barley Qingyin 3506 showed low BAT in the two-point assay and exhibited a rapid decline in RRBAA with increasing duration of heat treatment. The RRBAA of these genotypes declined to below $32 \%$ in the first $10 \mathrm{~min}$ and to around $10 \%$ after $20 \mathrm{~min}$ of heat treatment in 2009, and to below $13 \%$ in the first $10 \mathrm{~min}$ and to around 5\% after $20 \mathrm{~min}$ of heat treatment in 2012. XZ11 and Allaweinuw showed moderate BAT in the two-point assay and also had intermediate BAT with increasing duration of heat treatment, with the RRBAA being below 71\% in the first $10 \mathrm{~min}$, about $50 \%$ after $20 \mathrm{~min}$ and 35\% after $30 \mathrm{~min}$ in 2009, and about $52 \%$ after $10 \mathrm{~min}$, $32 \%$ after $20 \mathrm{~min}$, and $10 \%$ after $30 \mathrm{~min}$ of heat treatment in 2012.

To identify elite genotypes or accessions with high BAA and BAT, three wild barley accessions, i.e., XZ25, XZ31, and XZ174, with BAA over $1500 \mathrm{U} / \mathrm{g}$, and cultivar Fuxuan 48, with BAA over $1100 \mathrm{U} / \mathrm{g}$ in 2009, were selected to confirm their BAT within $1 \mathrm{~h}$ of treatment at $60^{\circ} \mathrm{C}$ (Fig. 4). The changes in RRBAA values in response to heat treatment for the four genotypes were very similar in the two years, except for XZ31, which showed a slight difference between 2009 and 2012.

\section{Discussion}

The two-point assay method was used by Eglinton et al. (1998) to determine BAT. In the current study, this method was employed to measure the BAT of 138 Tibetan wild barley accessions and 20 cultivated barley cultivars (Table 1). Eight genotypes with a large difference in BAT were further used to investigate the responses of BAT to the temperature and duration of heat treatment (Figs. 3 and 4). The RRBAA value, an indicator of BAT, differed among the genotypes examined, and some wild barley accessions, including XZ174, XZ31, and XZ25, showed high BAT. Our results showed that the two-point assay is efficient for the determination of BAT in a large population. 


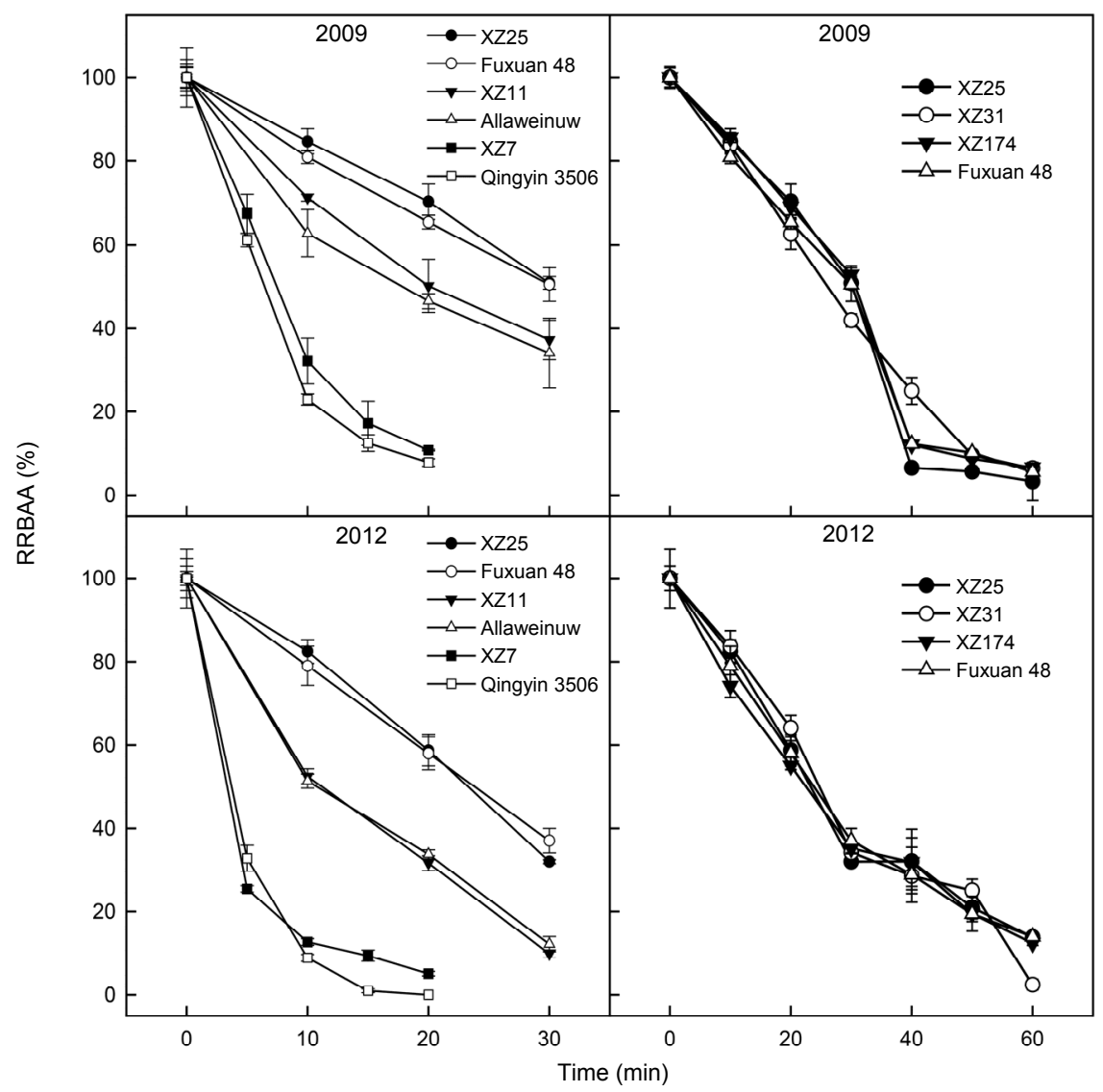

Fig. 4 Change in RRBAA with duration of heat treatment

$\beta$-Amylase extract of each genotype was incubated at $60{ }^{\circ} \mathrm{C}$ for $30 \mathrm{~min}$ (left panels) or $60 \mathrm{~min}$ (right panels). The germplasm coded XZ is Tibetan wild barley. Each value is the mean of three replicates for each genotype. Bars represent standard errors

Wei et al. (2009a) reported the BAA of $76 \mathrm{Ti}-$ betan wild barley accessions planted in two locations, Hangzhou and Wuhan, China in the 2006 and 2007 growing seasons, and found a large difference among these wild accessions. In the present study, we found a wider variation in BAA among wild barleys than among cultivated barleys. Moreover, there was an obvious difference between the two years, although there was a significant correlation between the years. Similarly, we found a large difference in BAT among barley genotypes and between years, and the wild barley accessions showed a wider variation than cultivated barley. A significant correlation between the two years in BAT was also found. So we conclude that BAT, like BAA, is affected by both genetic and environmental factors. Concerning the weather during the grain filling stage, 2012 had lower temperatures and more rainfall than 2009. In a previous study, we found that high temperatures during the filling stage could cause higher BAA (Wei et al., 2009b). The current results suggest that BAT varies in relation to temperature and rainfall.

Tibetan wild barley is considered as one of the progenitors of cultivated barley (H. vulgare) and is rich in genetic diversity (Dai et al., 2012). Recently, it was shown that wild barley contained special germplasm with high tolerance to abiotic stresses, such as salinity and drought (Zhao et al., 2010; Qiu et al., 2011; Wu et al., 2011). The current study showed that Tibetan wild barleys have wide genetic variation in BAA and BAT. For malting or brewing use, both the BAA and BAT of barley grains are important for the starch-degrading process (Eglinton et al., 1998; Wang et al., 2003). BAA and BAT are controlled by quantitative loci, including the Bmyl allele, which is located in the long arm of chromosome $4 \mathrm{H}$ (Erkkilä et 
al., 1998; Kaneko et al., 2001b; Clancy et al., 2003). In this study, the BAAs and BATs of Tibetan wild and cultivated barleys were compared. As a result, some wild accessions were identified which have higher BAA and BAT than those reported previously (Eglinton et al., 1998; Filichkin et al., 2010; Vinje et al., 2010). These genotypes will be useful for the improvement of malt quality through breeding programs.

\section{Conclusions}

Tibetan wild barleys showed wider distributions of BAA and BAT than cultivated barleys in the two years of experiments. Both BAA and BAT were greatly affected by the genotype and the environment. There was a significant difference among barley genotypes in the response of RRBAA to the temperature and duration of heat treatment. These findings will be helpful for the improvement of BAA and BAT in malt barley.

\section{Compliance with ethics guidelines}

Hai-tao ZHANG, Tian-long CHEN, Bing-lin ZHANG, De-zhi WU, Ye-chang HUANG, Fei-bo WU, and Guo-ping ZHANG declare that they have no conflict of interest.

This article does not contain any studies with human or animal subjects performed by any of the authors.

\section{References}

Agu, R.C., 2003. Some relationships between malted barleys of different nitrogen levels and the wort properties. J. Inst. Brew., 109(2):106-109. [doi:10.1002/j.2050-0416.2003. tb00137.x]

Agu, R.C., Brosnan, J.M., Bringhurst, T.A., et al., 2007. Influence of corn size distribution on the diastatic power of malted barley and its impact on other malt quality parameters. J. Agric. Food Chem., 55(9):3702-3707. [doi:10 1021/jf0636059]

Ahokas, H., Manninen, M.L., 2000. Thermostabilities of grain $\beta$-amylase and $\beta$-glucanase in Finnish landrace barleys and their putative past adaptedness. Hereditas, 132(2): 111-118. [doi:10.1111/j.1601-5223.2000.00111.x]

Clancy, J.A., Han, F., Ullrich, S.E., et al., 2003. Comparative mapping of $\beta$-amylase activity QTLs among three barley crosses. Crop Sci., 43(3):1043-1052. [doi:10.2135/cropsci 2003.1043]

Dai, F., Nevo, E., Wu, D.Z., et al., 2012. Tibet is one of the centers of domestication of cultivated barley. PNAS, 109(42):16969-16973. [doi:10.1073/pnas.1215265109]

Delcour, J.A., Verschaeve, S.G., 1987. Malt diastatic activity. Part II. A modified EBC diastatic power assay for the selective estimation of $\beta$-amylase activity. Time and temperature dependence of the release of reducing sugars. J. Inst. Brew., 93(4):296-301. [doi:10.1002/j.2050-0416. 1987.tb04506.x]

Eglinton, J.K., Langridge, P., Evans, D.E., 1998. Thermostability variation in alleles of barley $\beta$-amylase. J. Cereal Sci., 28(3):301-309. [doi:10.1016/S0733-5210(98)90010-8]

Erkkilä, M.J., Leah, R., Ahokas, H., et al., 1998. Alleledependent barley grain $\beta$-amylase activity. Plant Physiol., 117(2):679-685. [doi:10.1104/pp.117.2.679]

Evans, E., van Wegen, B., Ma, Y.F., et al., 2003. The impact of the thermostability of $\alpha$-amylase, $\beta$-amylase, and limit dextrinase on potential wort fermentability. J. Am. Soc. Brew. Chem., 61(4):210-218.

Filichkin, T.P., Vinje, M.A., Budde, A.D., et al., 2010. Phenotypic variation for diastatic power, $\beta$-amylase activity, and $\beta$-amylase thermostability vs. allelic variation at the Bmyl locus in a sample of North American barley germplasm. Crop Sci., 50(3):826-834. [doi:10.2135/cropsci 2009.04.0231]

Gibson, T.S., Solah, V., Holmes, M.R.G., et al., 1995. Diastatic power in malted barley - contributions of malt parameters to its development and the potential of barleygrain $\beta$-amylase to predict malt diastatic power. J. Inst. Brew., 101(4):277-280. [doi:10.1002/j.2050-0416.1995. tb00867.x]

Gong, X., Westcott, S., Zhang, X.Q., et al., 2013. Discovery of novel Bmyl alleles increasing $\beta$-amylase activity in Chinese landraces and Tibetan wild barley for improvement of malting quality via MAS. PLoS ONE, 8(9):e72875. [doi:10.1371/journal.pone.0072875]

Hara-Nishimura, I., Nishimura, M., Daussant, J., 1986. Conversion of free $\beta$-amylase to bound $\beta$-amylase on starch granules in the barley endosperm during desiccation phase of seed development. Protoplasma, 134(2-3): 149-153. [doi:10.1007/BF01275713]

Hardie, D.G., 1975. Control of carbohydrase formation by gibberellic-acid in barley endosperm. Phytochemistry, 14(8):1719-1722. [doi:10.1016/0031-9422(75)85281-2]

Kaneko, T., Zhang, W.S., Takahashi, H., et al., 2001a. QTL mapping for enzyme activity and thermostability of $\beta$-amylase in barley (Hordeum vulgare L.). Breeding Sci., 51(2):99-105. [doi:10.1270/jsbbs.51.99]

Kaneko, T., Zhang, W.S., Ito, K., et al., 2001b. Worldwide distribution of $\beta$-amylase thermostability in barley. Euphytica, 121:223-228. [doi:10.1023/A:1012095811104]

McCleary, B.V., Codd, R., 1989. Measurement of $\beta$-amylase in cereal flours and commercial enzyme preparations. $J$. Cereal Sci., 9(1):17-33. [doi:10.1016/S0733-5210(89) 80018-9]

Qiu, L., Wu, D.Z., Ali, S., et al., 2011. Evaluation of salinity tolerance and analysis of allelic function of $H v H K T 1$ and HvHKT2 in Tibetan wild barley. Theor. Appl. Genet., 122(4):695-703. [doi:10.1007/s00122-010-1479-2]

Sjöholm, K., Macri, L.J., MacGregor, A.W., 1995. Is there a role for limit dextrinase in mashing? In: Proceedings of 
the European Brewing Convention Congress. Brussels, p.277-284.

Thacker, S.P., Ramamurthy, V., Kothari, R.M., 1992. Characterisation of barley $\beta$-amylase for application in maltose production. Starch, 44(9):339-341. [doi:10.1002/star. 19920440906]

Ullrich, S.E., Han, F., Jones, B.L., 1997. Genetic complexity of the malt extract trait in barley suggested by QTL analysis. J. Am. Soc. Brew. Chem., 55(1):1-4.

Vinje, M.A., Duke, S.H., Henson, C.A., 2010. Utilization of different Bmyl intron III alleles for predicting $\beta$-amylase activity and thermostability in wild and cultivated barley. Plant Mol. Biol. Rep., 28(3):491-501. [doi:10.1007/ s11105-009-0168-2]

Vinje, M.A., Willis, D.K., Duke, S.H., et al., 2011. Differential RNA expression of Bmyl during seed development and the association with $\beta$-amylase accumulation, activity, and total protein. Plant Physiol. Biochem., 49(1):39-45. [doi:10.1016/j.plaphy.2010.09.019]

Wang, J.M., Zhang, G.P., Chen, J.X., et al., 2003. Genotypic and environmental variation in barley $\beta$-amylase activity and its relation to protein content. Food Chem., 83(2): 163-165. [doi:10.1016/S0308-8146(03)00058-X]
Wei, K., Xue, D.W., Jin, X.L., et al., 2009a. Genotypic and environmental variation of $\beta$-amylase activity, $\beta$-glucan and protein fraction contents in Tibetan wild barley. $J$. Zhejiang Univ. (Agric. Life Sci.), 35(6):639-644 (in Chinese). [doi:10.3785/j.issn.1008-9209.2009.06.008]

Wei, K., Dai, F., Wu, F.B., et al., 2009b. The variation of $\beta$-amylase activity and protein fractions in barley grains as affected by genotypes and post-anthesis temperatures. J. Inst. Brew., 115(3):208-213. [doi:10.1002/j.2050-0416. 2009.tb00370.x]

Wu, D.Z., Qiu, L., Xu, L.L., et al., 2011. Genetic variation of $H v C B F$ genes and their association with salinity tolerance in Tibetan annual wild barley. PLoS ONE, 6(7):e22938. [doi:10.1371/journal.pone.0022938]

Zhao, J., Sun, H.Y., Dai, H.X., et al., 2010. Difference in response to drought stress among Tibet wild barley genotypes. Euphytica, 172(3):395-403. [doi:10.1007/s10681009-0064-8]

Zhou, M., 2010. Barley production and consumption. In: Zhang, G., Li, C. (Eds.), Genetics and Improvement of Barley Malt Quality. Springer Berlin Heidelberg, p.1-17. [doi:10.1007/978-3-642-01279-2_1]

\section{中文㔍要：}

\section{本文题目: 青藏高原一年生野生大麦和栽培大麦中 $\boldsymbol{\beta}$-淀粉酶活性和热稳定性的基因型变异}

Variation in $\beta$-amylase activity and thermostability in Tibetan annual wild and cultivated barley genotypes

研究目的: $\beta$-淀粉酶活性 (BAA) 与热稳定性 (BAT) 是啤用大麦品质的重要性状, 本研究旨在明确青 藏高原一年生野生大麦 BAA 和 BAT 的基因型差异, 鉴定可用于啤用大麦品质育种的特异种 质材料。

创新要点: 青藏高原一年生野生大麦中具有高 BAA 和 BAT 的基因型, 可为啤用大麦品质育种提供特异 遗传材料; 解析了不同温度与高温处理不同时间对 BAT 的影响及其机理。

研究方法: 本研究以 138 个青藏高原一年生野生大麦基因型和 20 个栽培大麦品种为材料, 在杭州大田 条件下种植两年（2008 2009 年和 2011 2012 年）, 利用 Megazyme 公司研制的试剂盒 BETAMYL- ${ }^{\circledR}$ kit 法测定 BAA, 用两点法测定 BAT。

重要结论: BAA 和 BAT 在供试的基因型之间均有显著的差异, 且野生大麦的基因型变异明显大于栽培 品种，青藏高原一年生野生大麦中具有高 BAA 和 BAT 值的野生大麦材料。

关键词组: 大麦; $\beta$-淀粉酶活性; 热稳定性; 青藏高原 